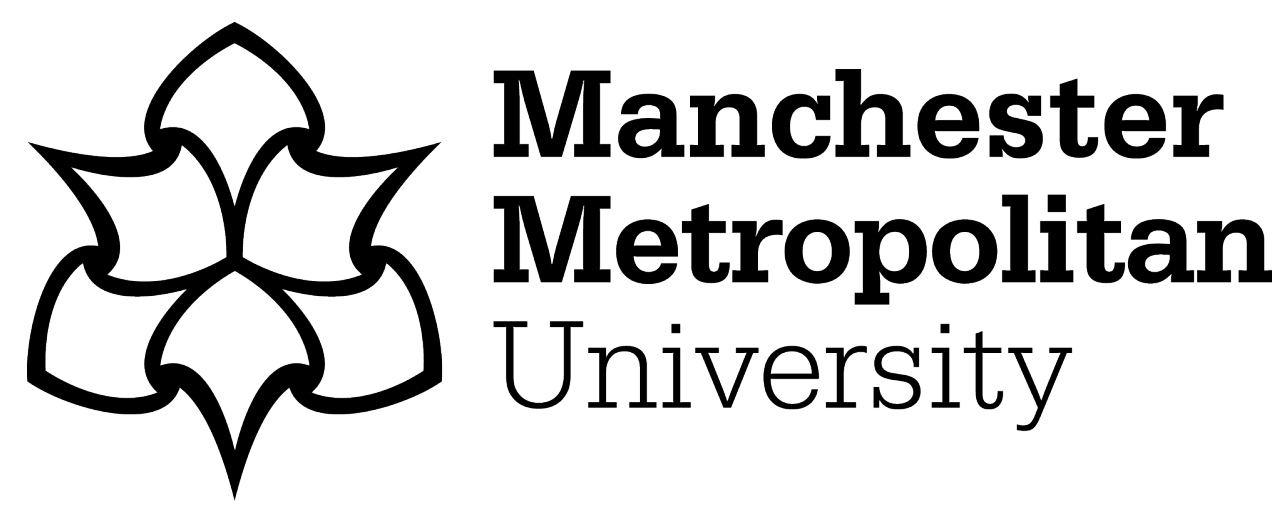

Ayu Nariswari, NP, Bamford, D ORCID logoORCID: https://orcid.org/00000002-1050-1357 and Dehe, B ORCID logoORCID: https://orcid.org/00000002-3016-1871 (2019) Testing an AHP model for aircraft spare parts. Production Planning and Control, 30 (4). pp. 329-344. ISSN 0953-7287

Downloaded from: https://e-space.mmu.ac.uk/623141/

Version: Accepted Version

Publisher: Taylor \& Francis

DOI: https://doi.org/10.1080/09537287.2018.1555341

Please cite the published version 
Accepted Submission to Production Planning and Control

Manuscript ID - TPPC-2018-0163

November 2018

Title: Testing an AHP Model for Aircraft Spare Parts

Author Names:

Ni Putu Ayu Nariswari, nariswari.ayu@gmail.com

GMF AeroAsia, Kota Jakarta Timur, Daerah Khusus Ibukota Jakarta 13650

David Bamford, d.r.bamford@hud.ac.uk (Corresponding Author)

Huddersfield Business School, University of Huddersfield, Queensgate, Huddersfield, HD1 3DH, UK

0044 (0)1484 472278

Benjamin Dehe, B.Dehe@hud.ac.uk

Huddersfield Business School, University of Huddersfield, Queensgate, Huddersfield, HD1 3DH, UK 


\title{
Testing an AHP Model for Aircraft Spare Parts
}

\begin{abstract}
This research aims to develop and test a practical and precise multi-criteria classification of aircraft spare part inventory management, using the Analytical Hierarchy Process (AHP), in order to maintain aircraft operational availability and to reduce unnecessary downtime. In this study, a multi-criteria model is developed within a large-scale aircraft maintenance and repair firm, in Indonesia. Spare parts data was extracted from the inventory system and analysed to triangulate the model outcome, demonstrate its validity and compare the results against the mathematical results generated by the system's algorithm. The findings suggest that AHP can lead to a transparent, rapid and systematic classification model, this is highly accurate and precise with an outcome comparable to traditional methods. The conclusion proposes that the AHP classification model is more effective and transparent than the currently available mathematical methods. This research contributes to the development of the multi-criteria inventory classification literature in the context of the aviation industry.
\end{abstract}

Key words: AHP; Inventory Classification; Aircraft Spares

\section{Introduction}

Maintenance is the backbone of successful aircraft operations (Bazargan, 2015). Aircraft maintenance, repair, and overhaul (MRO) is a complex process that has stringent regulations established by airworthiness authorities (Vieira and Loures, 2016). According to IATA (2015), civil aviation spent $\$ 62.1$ B on aircraft maintenance in 2014, accounting for nine per cent of the total airline operating costs (IATA, 2015). A significant MRO cost factor for airlines is the disruption of the use of aircraft during maintenance. The opportunity loss during maintenance costs approximately from tens of thousands to a hundred thousand dollars per day (Erkoc and Ertogral, 2016). Therefore, reducing the maintenance lead time is a core objective of aircraft MRO.

To maintain the operation of aircraft, airlines need to ensure aircraft availability by reducing unnecessary downtime, for example delays and cancellations (Regattieri et al., 2015). A study from Knotts (1999) reveals that 20\% of unnecessary downtime occurs because of technical reasons. Moreover, Marais and Robichaud (2012) suggest that improper maintenance accounts for a significant proportion of aircraft accidents and incidents. Therefore, appropriate maintenance is needed to reduce unnecessary downtime, provide safety, and maintain/increase passenger satisfaction. 
One of the commonly used strategies to avoid lengthy maintenance downtime is to replace the failed item immediately with a functioning spare part (Karsten and Basten, 2014). Some aircraft parts are very expensive and critical, for example, wheels and brakes can cost USD 4 million (de Souza et al., 2011). Some of them have long lead times and high variation of the 'Mean Time Between Unscheduled Removal' (MTBUR) according to Wang and Yue, (2015). Hence, an excess spare part inventory requires a significant amount of capital investment and can impede cash flow, which should be avoided (Gu et al., 2015). IATA (2015) reports that the average value of inventory is USD 2.6 million per aircraft. The unavailability of one component can lead to unproductive aircraft downtime $(\operatorname{Rad}$ et al., 2011), with a direct consequence on the company profit (Sarker and Haque, 2000). Therefore, inventory decision-making becomes critical in the aviation industry. Perssona and Saccani (2008), Syntetos et al. (2009) suggest that spare part classification can improve inventory management decision-making. Therefore, multi-criteria classification of aircraft spare part inventory management is a potential solution that needs to be investigated and tested.

In recent years, a considerable amount of literature on spare part multi-criteria inventory classification in the manufacturing industry has been published (Rezaei and Dowlatshahi, 2010; Hadi-Vencheh and Mohamadghasemi, 2011; Molenaers et al., 2012; Lolli et al., 2014; Baykasoglu et al., 2016). However, the application for the aviation industry is assumed to be partly different because of the dynamic nature of the system. Therefore, studies in the aircraft industry are necessary to empirically test and assess the effectiveness of using MCDA as an inventory classification model. Moreover, very few studies have investigated the inventory classification of aircraft spare parts (c.f. Wang and Kang, 2007; Rad et al., 2011), which leads this study to contribute to this specific underdeveloped field. Moreover, a literature analysis and industrial assessment study by Roda et al. (2014) show that a gap between research and practice is still present. Bacchetti and Saccani (2012) also mention that there is a strong need for case studies, describing concrete implementation of classification methods and focusing on the practical applicability.

Based on the established gap, this paper develops and tests a multi-criteria inventory classification model using AHP for aircraft spare parts management. To guide the study, two research questions (RQs) are delevoped: i) what are the criteria and sub-criteria to be considered to develop a relevant MCDA model for an aircraft spare part classification system? ii) To what extent is the AHP a practical and effective solution as a multi-criteria spare part classification system compare to the traditional methods? 


\section{Literature review}

\subsection{Aircraft Spare Part Inventory}

Conventionally, aircraft MRO could be seen as a service industry that only offers aircraft maintenance services to airlines (Ayeni et al., 2016). The expansion of 'productisation' business strategy in MRO industry has led airlines outsourcing most of their spare part availability to the MRO (Ayeni et al., 2011; Al-kaabi et al. 2007). Harkonen et al. (2016) define 'productisation' as the process of analysing the needs of the customer, combining tangible and intangible elements into a product-like object. This business strategy has driven MRO spare part management to shift from a supporting unit to a business unit.

Airlines aim to reduce aircraft downtime to reduce cost and maximize revenue while flying (Friend, 1992). The downtime itself costs from tens of thousands to a hundred thousand dollars per day (Erkoc and Ertogal, 2016). Replacing a failed part immediately with a functioning spare part is called repair-by-replacement (Muckstadt, 2005). However, this strategy only works when the spare part is available in inventory (Perssona and Saccani (2008). Therefore, the necessary high level of inventory raises costs for the supply chain (Chopra and Meindl, 2016). Inventory-related costs require a significant amount of money and have already stifled some industries' development (Kennedy et al., 2002). In 2002, the aviation inventory level was estimated to be over USD 50 billion (McDonald, 2002). In contrast, expenditure on commercial aircraft maintenance was estimated to be USD 34 billion (Flint, 2002). Compared to this figure, the aviation inventory level of USD 50 billion seems quite significant (Kilpi and Vepsalainen, 2004).

These conditions shape the operations objective of aircraft MRO to be responsive, fast, reliable, and cost effective. Aircraft MRO needs to maintain the availability of spare parts for immediate disposition when required to minimise maintenance downtime. However, inventory is limited by its cost. Therefore, designing the spare part inventory in an optimal way represents a demanding and crucial task for production managers (Braglia et al., 2004). A recent study from Driessen et al. (2015) provides the framework of spare part inventory management, which always begins with the classification of spare parts.

\subsection{Spare Part Inventory Management Classification}

The objective of inventory management is to have the requisite material ready to be processed at the right time at minimum cost (Cakir and Canbolat, 2008; Gomez, A. and Carnero, 2011). Spare part inventory management is often regarded as a special case because 
of its distinct characteristics, i.e. low and intermittent demand volume, therefore drawing much attention from researchers (de Souza et al., 2011). In general, there are two main approaches to spare part inventory optimisation: i) mathematical models and ii) classification approaches (Huiskonen, 2001). Mathematical models usually focus on optimising inventory cost and service level regarding economic order quantity and reorder point. However, these methodologies do not consider several intangible or subjective factors, for example, the characteristics of the product, the quality of the supplier, the safety objectives, the supply characteristics, the loss of production impact, and the type of maintenance required (Braglia et al., 2004). Moreover, when the inventory is large, the computation becomes difficult (Lolli et al., 2014). Therefore, spare part classification becomes necessary to allow the decisionmakers to concentrate on the most important items to simplify the inventory decision-making process (Syntetos et al., 2009).

\subsubsection{Spare Part Classification Criteria}

Identifying criteria that determine the spare part classification is crucial. However, there is no consensus in the literature about the most appropriate criteria to consider in classifying spare parts. Cohen et al., (1997) show that a significant amount of subjective judgement is used to define the criteria in practice. The literature review for this research identified that the most common criteria used in classifying spare parts relate to the 'lead time' and 'demand for items'; other common criteria are 'price' and 'criticality', fewer studies stating 'reliability' and the 'number of suppliers', as compiled in Table 1. 
Table 1 - Citations frequency of Spare Part Criteria

\begin{tabular}{|c|c|c|c|c|c|c|c|c|c|}
\hline No & Publications & $\begin{array}{l}\text { Lead } \\
\text { time }\end{array}$ & Demand & Price & Criticality & Specificity & Reliability & $\begin{array}{l}\text { No of } \\
\text { supplier }\end{array}$ & Other \\
\hline 1 & Duchessi et al. (1988) & $X$ & $\mathrm{X}$ & & $\mathrm{X}$ & & & & \\
\hline 2 & Gajpal et al. (1994) & $\mathrm{X}$ & & & $X$ & $\mathrm{X}$ & & & \\
\hline 3 & Huiskonen (2001) & & $\mathrm{X}$ & $\mathrm{X}$ & $\mathrm{X}$ & $X$ & & & $\mathrm{X}$ \\
\hline 4 & Braglia (2004) & $\mathrm{X}$ & $\mathrm{X}$ & $\mathrm{X}$ & $\mathrm{X}$ & $X$ & & & $\mathrm{X}$ \\
\hline 5 & Ramanathan (2006) & $\mathrm{X}$ & $\mathrm{X}$ & $X$ & $\mathrm{X}$ & & & & \\
\hline 6 & $\mathrm{Ng}(2007)$ & $\mathrm{X}$ & $\mathrm{X}$ & $\mathrm{X}$ & & & & & \\
\hline 7 & Wang \& Kang (2007) & $\mathrm{X}$ & $\mathrm{X}$ & $\mathrm{X}$ & & & & & \\
\hline 8 & Zhou \& Fan (2007) & $\mathrm{X}$ & $\mathrm{X}$ & $\mathrm{X}$ & & & & & \\
\hline 9 & $\begin{array}{l}\text { Cakir \& Canbolat } \\
(2008)\end{array}$ & $\mathrm{X}$ & $\mathrm{X}$ & $\mathrm{X}$ & $\mathrm{X}$ & $X$ & & & $\mathrm{X}$ \\
\hline 10 & $\begin{array}{l}\text { Rezaei \& Dowlatshahi } \\
(2010)\end{array}$ & $\mathrm{X}$ & $\mathrm{X}$ & $\mathrm{X}$ & & & $\mathrm{X}$ & & \\
\hline 11 & $\begin{array}{l}\text { Hadi-Vencheh \& } \\
\text { Mohamadghasemi } \\
\text { (2011) }\end{array}$ & $\mathrm{X}$ & $\mathrm{X}$ & & & & & & $\mathrm{X}$ \\
\hline 12 & Rad et al. (2011) & $\mathrm{X}$ & $\mathrm{X}$ & $\mathrm{X}$ & & & $\mathrm{X}$ & & \\
\hline 13 & $\begin{array}{l}\text { Moleaners et al. } \\
(2012)\end{array}$ & $\mathrm{X}$ & $\mathrm{X}$ & & $\mathrm{X}$ & & & $\mathrm{X}$ & $\mathrm{X}$ \\
\hline 14 & Lolli et al. (2014) & $X$ & $X$ & & $\mathrm{X}$ & & & & \\
\hline 15 & Stoll et al. (2015) & $X$ & $X$ & & & & & & $\mathrm{X}$ \\
\hline 16 & $\begin{array}{l}\text { Baykasoglu et al. } \\
(2016)\end{array}$ & $\mathrm{X}$ & & $\mathrm{X}$ & $\mathrm{X}$ & & $\mathrm{X}$ & $X$ & $X$ \\
\hline & Total & 15 & 14 & 10 & 9 & 4 & 3 & 2 & 7 \\
\hline
\end{tabular}

There also appears to be a mismatch in the importance of the criteria between the industry and the academic literature. From a practitioner perspective, 'criticality' seems to be the most important factor, for instance, Huiskonen (2001) and Dekker et al., (1998) explained that a part's criticality is the first aspect considered by practitioners in analysing spare part characteristics. However, 'lead-time', 'demand' and 'price' are highly considered in the academic literature, as per Table 1 (e.g. Gajpal et al., 1994 and Lolli et al., 2014). Process criticality is the consequence for operations caused if the replacement part is not available. Control criticality is related to the possibilities to control the situation, such as lead time and the availability of suppliers. Cavalieri et al. (2008) suggest that the expertise required for making stocking strategy decisions for MRO is different from that of the manufacturing industry. It is not merely based on the material department but also involves the technical and maintenance departments. A survey by Roda et al. (2014) proves the theory and reveals that 
the most prevalent criteria used in the industry are the part's criticality, as one hundred per cent of the respondents chose it. This notable finding shows a mismatch in the criteria perception between the literature and the industry.

Aircraft spare part characteristics are peculiar compared to those of other industrial spare parts. In general, there are two types of aircraft spare parts: i) repairable parts, which are technically and economically repairable, and ii) consumable parts, which are scrapped after replacement. Aircraft parts are distinguished by a large number of spare parts; for instance, the recommended number of spare parts for one aircraft type is around 3,000 (Srinivasan et al. 2014). Moreover, they also have a high variety of characteristics, such as variations in essentiality codes, MTBUR (mean time between unscheduled removal), scrap rates, and the airline's MEL (minimum equipment list). The demand itself has intermittent patterns (Wong et al., 2006). The sourcing of spares is often limited to one or a few suppliers, causing a constraint for procurement lead time and costs (Roda et al., 2014). Stock-out of one part potentially causes the costly downtime of aircraft (Driessen et al. 2015) and also cannibalisation of part (Srinivasan et al. 2014).

In the aviation industry, only a few studies have been conducted on aircraft spare part classification and Rad et al., (2011) developed an aircraft spare part classification using four factors: usage rate, unit price, lead time, and reliability. However, the criteria employed in the study might be assessed as incomplete by the aircraft industry sector as criticality is not included. In the aviation industry, part failure can directly affect passenger safety. The cost of delay and cancellation caused by spare part stock out also needs to be considered. Therefore, assessing the impact of spare part failure is vital. Rad et al., (2011) also suggest further research on aircraft spare part classification using other factors, such as reparability, scarcity, and part criticality.

\subsubsection{Spare Part Classification Method}

Several methods have been proposed for spare part classification. Traditional and straightforward classification methods such as quantitative $A B C$ classification have been widely applied in industries to determine the class of spare parts. In ABC classification, spare parts are categorised based on a single criterion, the usage value of the spare item (Partovi and Burton, 1993). ABC classification has proven easy to use and performs well in homogenous and one-criterion inventory management (Ramanathan, 2006; Partovi and Anandarajan, 2002). However, as the variety of a spare part's control characteristics increases, this one-dimensional classification does not address all the control criteria of 
different items (Huiskonen, 2001). Moreover, Teunter et al., (2010) explain that ABC classification is a cost-inefficient solution for inventory management but it can be improved by including a cost criterion. Therefore, it is recognised that $\mathrm{ABC}$ classification may not be able to provide adequate classification in highly complex environment. Gomez and Carnero, (2011) described the use of Computerised Maintenance Management Systems in their paper on a regional health system. The other commonly used classification method is VED classification, a qualitative method based on consultation with experts (Mukhopadhyay et al., 2003). Spare parts are classified as vital (V), essential (E), and desirable (D) items. Despite its apparent simplicity, VED classification might be difficult because the implementation is based solely on maintenance experts' subjective judgement (Cavalieri et al., 2008). The standard methods of spare part classification that involve judgement from engineers, material managers, quality control staff and other experts might lead to some disagreements among experts about the exact importance of spare parts (Duchessi et al., 1988). Therefore, more analysis based on hard data is preferable. To overcome this limitation, some researchers have developed multi-criteria classification models, which can manage multiple factors and cope with the complexity of the decision (Braglia et al., 2004).

Multi-criteria inventory classification was first introduced by Flores and Whybark (1987) using a joint criteria matrix. In the spare part context, Duchessi et al., (1988) first introduced a two-dimensional classification spare part inventory scheme using two criteria, inventory cost and criticality, which are defined by simultaneously considering downtime cost, lead time, and the number of failures per unit. This proposed method is rather difficult to apply in the industry because of the complex computation. Table 2 highlights the advantages and disadvantages of classification methods and also shows aspects of the chronology.

Table 2 - Advantages and Disadvantages of Classification Methods / Chronology

\begin{tabular}{|c|c|c|c|}
\hline Methods & Scientific Publications & Advantages & Disadvantages \\
\hline $\begin{array}{l}\text { Two-dimensional } \\
\text { method }\end{array}$ & Duchessi et al. (1988) & $\begin{array}{l}\text { Strong conceptual } \\
\text { groundwork }\end{array}$ & $\begin{array}{l}\text { Difficult practical } \\
\text { applicability }\end{array}$ \\
\hline $\begin{array}{l}\text { Weighted linear } \\
\text { optimisation }\end{array}$ & $\begin{array}{l}\text { Ramanathan (2006) } \\
\text { Ng (2007) } \\
\text { Zhou and Fan (2007) }\end{array}$ & Can be easily understood & $\begin{array}{l}\text { Cannot consider } \\
\text { categorical data }\end{array}$ \\
\hline $\begin{array}{l}\text { Fuzzy linear } \\
\text { assignment }\end{array}$ & Baykasoglu et al. (2016) & $\begin{array}{l}\text { Considers fuzziness in the } \\
\text { group hierarchy and } \\
\text { quantitative type criteria }\end{array}$ & $\begin{array}{l}\text { Difficult practical } \\
\text { applicability }\end{array}$ \\
\hline
\end{tabular}




\begin{tabular}{|c|c|c|c|}
\hline Methods & Scientific Publications & Advantages & Disadvantages \\
\hline AHP & $\begin{array}{l}\text { Gajpal et al. }(1994) \\
\text { Braglia et al. }(2004) \\
\text { Wang and Kang (2007) } \\
\text { Rad et al. }(2011) \\
\text { Moleaners et al. }(2012) \\
\text { Stoll et al. }(2015)\end{array}$ & $\begin{array}{l}\text { Transparency and user } \\
\text { friendliness } \\
\text { Integrates qualitative and } \\
\text { quantitative aspects }\end{array}$ & Subjective judgement \\
\hline AHP K-Veto & Lolli et al. (2014) & $\begin{array}{l}\text { Full compensatory } \\
\text { methods }\end{array}$ & $\begin{array}{l}\text { Inadequate to provide } \\
\text { an effective and } \\
\text { realistic analysis } \\
\text { Worsens the clustering } \\
\text { validity index }\end{array}$ \\
\hline Fuzzy AHP & $\begin{array}{l}\text { Cakir and Canbolat } \\
(2008)\end{array}$ & $\begin{array}{l}\text { Overcomes subjective } \\
\text { judgement }\end{array}$ & $\begin{array}{l}\text { Difficult practical } \\
\text { applicability }\end{array}$ \\
\hline Fuzzy AHP DEA & $\begin{array}{l}\text { Hadi-Vencheh and } \\
\text { Mohamadghasemi (2011) }\end{array}$ & $\begin{array}{l}\text { Overcomes subjective } \\
\text { judgement }\end{array}$ & $\begin{array}{l}\text { Difficult practical } \\
\text { applicability }\end{array}$ \\
\hline
\end{tabular}

The method introduced by Ramanathan (2006) uses a weighted linear optimisation method that can be easily understood by practitioners. Moreover, Zhou and Fan (2007) present an extended version of Ramanathan's model that resulted in a more reasonable and encompassing index. However, this method may require a long processing time when the number of items is large, and it cannot consider categorical data, such as a part's criticality ( $\mathrm{Ng}, 2007)$. Baykasoglu et al., (2016) introduces a fuzzy linear assignment method that incorporates fuzzy arithmetic and aggregation, fuzzy ranking, and fuzzy mathematical programming. This method considers the fuzziness in the group hierarchy and quantitative type criteria. However, this method is difficult to apply in the industry.

Other contributions to multi-criteria spare part classification use the analytical hierarchy process (AHP) method. AHP was introduced by Saaty (1980) as a multiple-criteria decision-making tool that uses a hierarchy as a representation of the system. AHP aims to assist people in organising their judgements to make a more effective decision (Saaty and Vargas, 2001; Subramanian and Ramanathan, 2012). The scale used in AHP classification ranges from 1 to 9 , which define the intensity of importance. The distinct feature of AHP is its flexibility to be integrated with different techniques that enable the user to gain benefits from all the combined methods (Vaidya and Kumar, 2006). Gajpal et al., (1994) propose the application of AHP with VED in classifying spare parts. Braglia et al., (2004) offer a multiattribute spare part tree analysis (MASTA) using the AHP method. The MASTA approach is based on two steps, recognising criticality classes using AHP and a decision diagram and selecting an inventory management policy (Braglia et al., 2004). Wang and Kang (2007), and Rad et al., (2011) proposed the AHP method for classifying aircraft spare parts. Molenaers et 
al., (2012) classify spare parts into four different levels of criticality using a combination of AHP and a 3D decision diagram. It is suggested that the primary advantages of the AHP method are the transparency and the user friendliness (Molenaers et al., 2012). A study by Stoll et al., (2015) also assigns a spare part classification to inventory management. The paper presents a three-dimensional spare-part classification using a decision tree and AHP. AHP is a flexible method to integrate qualitative and quantitative factors and allocate weights to the criteria. However, the drawback of this approach is the subjective judgement. To overcome this subjectivism, Cakir and Canbolat (2008) propose fuzzy AHP. However, this method is often complicated for practical application in the industry. The fuzzy AHP DEA (data envelopment analysis) method proposed by Hadi-Vhencheh and Mohamadghasemi (2011) faces the same difficulties for practical application. Lolli et al., (2014) introduce the hybrid AHP-K-Veto to provide a full compensatory method; however, it is inadequate to provide an effective and realistic analysis. Therefore, this study aims to develop and test an AHP model in order to i) demonstrate to what extent an MCDA model is a relevant and practical solution for an aircraft spare part classification system and ii) analyse to what extent is the AHP an effective modelling technique for a spare part classification system compared to the mathematical method?

\section{Methodology}

\subsection{The Case Study}

To address the aforementioned aims and research questions a single embedded-case study was designed with an aircraft MRO company in Indonesia. Case study research has the capacity to develop deep understanding of a phenomenon from the intensive and in-depth insight knowledge gathered by researchers based on a real-life problem (Saunders et al., 2016; Yin, 2014). Even though a single case study method generates some limitations related to the external validity and generalisation (Gay and Bamford, 2007; Yin, 2014), many important operational concepts have been developed by a single case study (Voss et al., 2002) and believed it is the adequate method in this instance.

\subsection{Data Collection}

Several methods can used to develop and populate MCDA models, such as focus group (Molenaers, 2012; Dehe and Bamford, 2015) structured and semi-structured interviews (Naesens et al., 2009; Falsini et al., 2012; Scott et al., 2013; Ahsan and Rahman, 2016) and surveys or questionnaires. Turban et al., (2011) found that business professionals mainly 
prefer verbal approaches such as group discussions and interviews over numerical approaches such as survey. Moreover, focus group discussions and multi-way interviews are considered suitable methods in MCDA modelling because of their ability to capture interactions between the decision-makers (Dehe and Bamford, 2015), even if they can be more difficult to set up (Bryman and Bell, 2011). Considering the time and resources limitations, semi-structured interviews were adopted in this research, which enabled capturing various perspectives among the different stakeholders involved (Easterby-Smith et al., 2008) in aircraft spare part inventory classification. The interview questions were a combination of open questions, probing questions, and specific questions.

Nine semi-structured interviews, as suggested by Scott et al., (2013), were conducted to investigate the relevant criteria for aircraft spare part classification. The interviewees are classified according to their function, three interviewees from airlines (referred to as A1, A2 and A3), three interviewees from engineering and maintenance department (technical, referred to as T1, T2 and T3) and three interviewees from the material department (supply, referred to as S1, S2 and S3). This arrangement was made to investigate the important criteria from the different stakeholders' perspective, when deciding aircraft spare part inventory management. Heterogeneous purposive sampling method was chosen to allow the researcher's judgement to choose the participants from different functions in the aircraft MRO (Saunders et al., 2016). The interviews were conducted face to face in the Indonesian language and all were audio recorded, with permission. In addition to the qualitative primary data collection, this research also required analysing the inventory data extracted from the company systems. This data set was used to compare the effectiveness and accuracy of multicriteria inventory management outcome against the existing inventory management mathematical model.

\subsection{Data Analysis}

The data was analysed using an abductive-based analytical procedure to i) explore the criteria and judgement of the practitioner in aircraft spare part criticality, ii) develop the hierarchical classification model, and iii) validate it through the subsequent data collection (Saunders et al., 2016). The qualitative research interview data was analysed using qualitative and quantitative methods. First, the audio-recorded data was transcribed and translated from the Indonesian language to English. Second, the qualitative data was analysed using template analysis methods to produce the hierarchical list (Saunders et al., 2016) of criteria used in the AHP classification model. AHP was used for its robustness and popularity (Saaty and 
Vargas, 2001). The template analysis started with a priori codes or coding templates generated from the literature conceptual model and the first interview (King, 2012). Third, the criteria weights are derived by transforming qualitative data into quantitative data using the content analysis method (Saunders et al., 2016). The content analysis process began with designing a coding schedule and coding manual (Bryman and Bell, 2011) based on the final coding template of the previous analysis. After that, the code was transformed into importance weights using the standard AHP scale of 1 to 9 (Dehe and Bamford, 2015; Saaty and Vargas, 2001). Then, the individual weights were aggregated into a group weight using a simple average (Goodwin and Wright, 1998). The fourth step was to develop the AHP model using criteria and weights from the previous process, and the final step was to implement the model for a number of spare parts and compare the results with those of the traditional method, current stock, and other literature methods. The data analysis can be summarised as: i) Audio recording of interviews transcribed and translated; ii) Analysed using template analysis method; iii) AHP criteria weights developed using content analysis method; iii) AHP model developed; iv) Use and apply AHP model for selected spare parts and compare.

\section{Findings}

\subsection{The Organisation}

This MRO company in Indonesia offers five types of aircraft maintenance: (1) line maintenance, (2) base maintenance, (3) component maintenance, (4) engine maintenance, and (5) other maintenance. As an aircraft $\mathrm{MRO}$, the organisation strongly depends on the availability of its technical spare parts to ensure the safety and continuity of aircraft operations. In this case, spare parts are needed to support the line: base components and engine maintenance, which are critical to ensure minimal downtime. Each hangar, shop and terminal is considered an internal client of the internal logistics provider, who is responsible for delivering the requested spare parts.

\subsection{The Inventory Management Problem}

At the time of the study, the company held more than 10 million SKUs in stock, representing a total stock value of more than USD 100 million. The spares are divided into two main categories: i) consumable, which are one-time-use spare parts, and ii) rotable, which are components that can be economically repaired repeatedly to a fully serviceable condition. The other notable difference between these rotable and consumable parts is their value. While the quantity of rotables in the company is only $1 \%$ of the total inventory, the value of rotable 
items accounts for two-thirds of the inventory value, while the consumable spare parts, which comprise $99 \%$ of the total inventory quantity, represent only a third of its value. IATA (2015) also indicates the value share of consumables, which is within a quarter to a third of the inventory value.

In relation to the actual demand, it is further revealed that $71 \%$ of rotable and $77 \%$ of consumable stock value has been static for the past six months. While most of the spare parts are slow moving, the risk of spare part unavailability is high for aircraft operation. The decision to select spare parts to be stocked is made by personnel from the material department, engineering department, maintenance department, and airlines. It is based on the spare part characteristic data from the manufacturers, personal experience, and judgement, which might not be necessarily captured or formally considered during the decision making process. The lack of a uniform method to combine the qualitative and quantitative characteristics of the spare parts, usually leads to either a surplus of financial resources or a high risk of important parts' unavailability. During the interviews both T1 and S2 explained how important were the experts' judgements to justify the qualitative aspects of the decision making. Experts' judgements depends on the personnel, lead to variations and differences between the fleets performances, a problem that could be reduced via the deployment of a MCDA model.

\subsection{Relevant criteria of aircraft spare part classification}

To identify the relevant criteria, semi-structured interviews were conducted with decisionmakers from airlines (A1, A2, A3), the engineering and maintenance department (T1, T2, T3), and the material department (S1, S2, S3). Figure 1 shows the model hierarchy of relevant criteria based on the template analysis results. This model is composed of three criteria 'Operational Criticality', 'Technical Characteristics' and Supply Characteristics', and 12 sub-criteria, which support the classification decision making process and identify the optimum alternative: Vital, Essential or Desirable. 


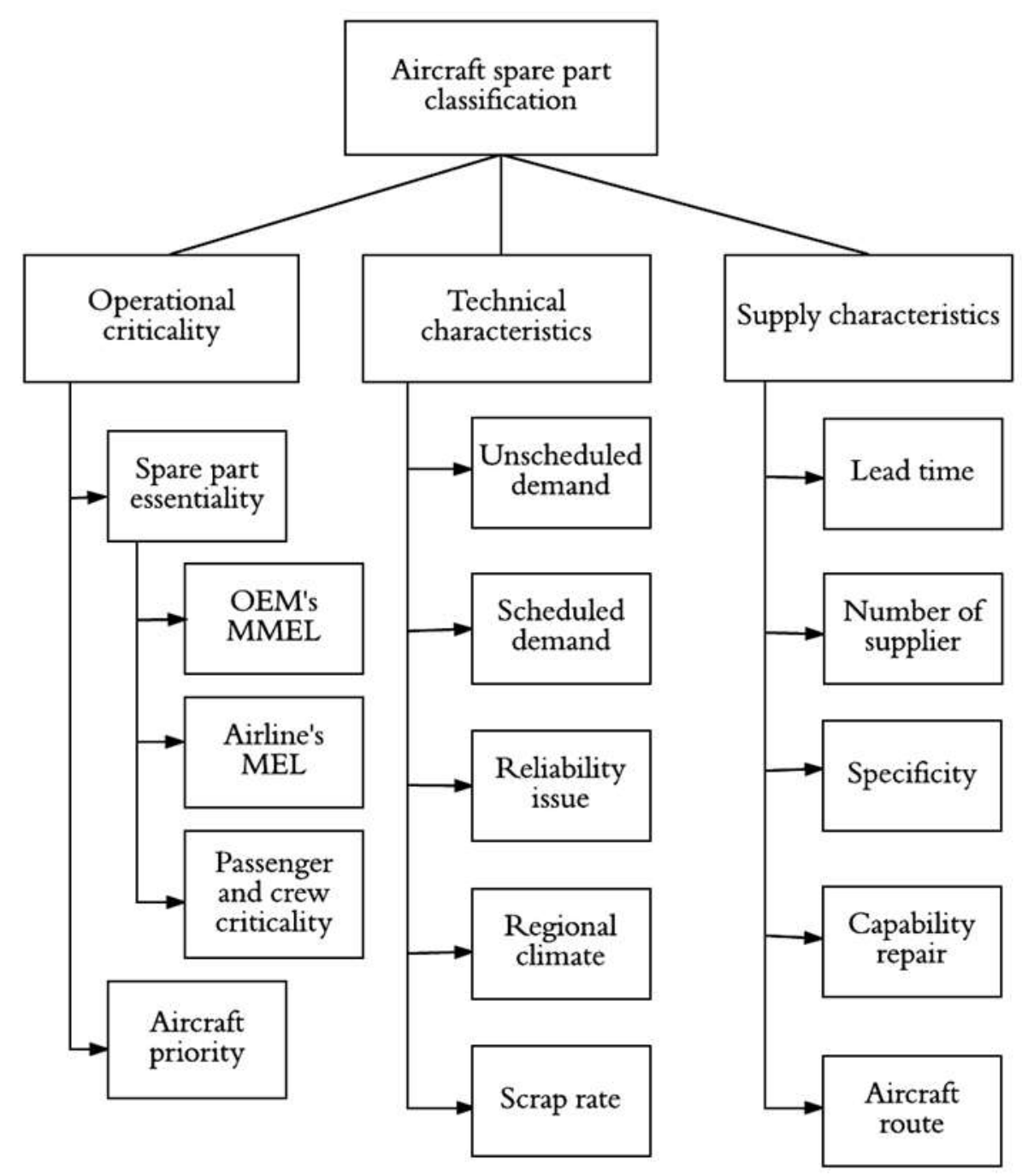

Figure 1 - MCDA Model

The weight of each sub-criteria were generated by converting the content analysis results code into individual weights using a 1 to 9 scale of importance. The respondent feedback ranged from less important to medium important to most important, these were weighted 1, 5 and 9. The individual judgement weight was aggregated to group the judgement weights using a simple average and are represented in Table 3. 
Table 3 - Individual and Group Weights of Sub-Criteria

\begin{tabular}{|l|r|r|r|r|r|r|r|r|c|c|}
\hline Sub-criteria & A1 & A2 & A3 & T1 & T2 & T3 & S1 & S2 & S3 & Weight \\
\hline 1. Spare part essentiality & 9 & 9 & 9 & 9 & 5 & 9 & 5 & 5 & 5 & 7.22 \\
\hline 1.1. OEM's essentiality & 9 & 9 & 9 & 9 & 1 & 1 & 5 & 1 & 1 & 5.00 \\
\hline $\begin{array}{l}\text { 1.2. Airline's essentiality } \\
\text { MEL) }\end{array}$ & 9 & 5 & 1 & 1 & 1 & 1 & 5 & 5 & 5 & 3.67 \\
\hline $\begin{array}{l}\text { 1.3. Passenger / Aircraft } \\
\text { crew }\end{array}$ & 7 & 5 & 7 & 7 & 1 & 1 & 7 & 9 & 1 & 5.00 \\
\hline 2. Aircraft priority & 5 & 5 & 7 & 1 & 1 & 1 & 1 & 1 & 1 & 2.56 \\
\hline 3. Unscheduled demand & 7 & 5 & 1 & 7 & 7 & 9 & 7 & 7 & 7 & 6.33 \\
\hline 4. Scheduled demand & 1 & 1 & 1 & 1 & 7 & 1 & 1 & 5 & 1 & 2.11 \\
\hline 5. Reliability issue & 5 & 1 & 1 & 9 & 5 & 7 & 7 & 7 & 5 & 5.22 \\
\hline 6. Regional climate & 5 & 1 & 1 & 5 & 7 & 1 & 1 & 5 & 5 & 3.44 \\
\hline 7. Scrap rate & 1 & 1 & 1 & 1 & 3 & 1 & 1 & 1 & 1 & 1.22 \\
\hline 8. Lead time & 7 & 9 & 9 & 9 & 5 & 9 & 7 & 5 & 7 & 7.44 \\
\hline 9. Number of supplier & 5 & 7 & 1 & 1 & 1 & 1 & 5 & 9 & 7 & 4.11 \\
\hline 10. Specificity & 1 & 1 & 1 & 1 & 1 & 1 & 7 & 7 & 1 & 2.33 \\
\hline 11. Capability repair & 1 & 1 & 1 & 1 & 5 & 1 & 5 & 5 & 1 & 2.33 \\
\hline 12. Route & 5 & 1 & 7 & 1 & 1 & 7 & 1 & 1 & 7 & 3.44 \\
\hline
\end{tabular}

On the other hand, the weight of a criterion is determined by its importance preference. Five respondents preferred the technical to the operational to the supply perspective. Three respondents preferred operational to technical to supply, and one respondent prefers operational to supply to technical. After the preferences aggregation process, it was revealed that the operational and technical perspectives have the same weight of 6.8 , while the supply perspective is lower at 1.4 , as shown in Table 4.

Table 4 - Importance Preference of Criteria

\begin{tabular}{|c|c|c|c|c|}
\hline Decision Maker & Preference & $\begin{array}{c}\text { Operational } \\
\text { criticality }\end{array}$ & $\begin{array}{c}\text { Technical } \\
\text { Characteristics }\end{array}$ & $\begin{array}{c}\text { Supply } \\
\text { Characteristics } \\
\end{array}$ \\
\hline A1 & $\mathrm{T}>\mathrm{O}>\mathrm{S}$ & 5 & 9 & 1 \\
\hline $\mathrm{A} 2$ & $\mathrm{O}>\mathrm{S}>\mathrm{T}$ & 9 & 1 & 5 \\
\hline A3 & $\mathrm{O}>\mathrm{T}>\mathrm{S}$ & 9 & 5 & 1 \\
\hline T1 & $\mathrm{T}>0>\mathrm{S}$ & 5 & 9 & 1 \\
\hline $\mathrm{T} 2$ & $\mathrm{~T}>0>\mathrm{S}$ & 5 & 9 & 1 \\
\hline T3 & $\mathrm{T}>0>\mathrm{S}$ & 5 & 9 & 1 \\
\hline S1 & $\mathrm{O}>\mathrm{T}>\mathrm{S}$ & 9 & 5 & 1 \\
\hline S2 & $\mathrm{T}>0>\mathrm{S}$ & 5 & 9 & 1 \\
\hline S3 & $\mathrm{O}>\mathrm{T}>\mathrm{S}$ & 9 & 5 & 1 \\
\hline \multicolumn{2}{|c|}{ Aggregate Judgement } & 6.8 & 6.8 & 1.4 \\
\hline
\end{tabular}




\subsection{Multi-criteria Inventory Classification Using AHP}

There are two steps in classifying spare part inventory management as follows: i) defining the spare part criticality and ii) defining the inventory strategy.

\subsubsection{Spare Part Criticality Classification}

The operational, technical, and supply criteria need to be considered in parallel according to the weight, not sequentially. However, evaluating the spare part criticality needs to be done sequentially, from the Original Equipment Manufacturers (OEM's) spare part essentiality, airline's spare part essentiality (the Minimum Equipment List - MEL), to the passenger and crew criticality. Therefore, the classification process can be made using AHP method with the application of decision diagram to classify the spare part essentiality. The spare part essentiality is defined by considering the OEM's essentiality, the airline's MEL essentiality, and passenger and crew criticality in a sequential manner. Based on the qualitative data collection the categorical measurement for each criterion is proposed on Table 5.

Table 5 - Categorical Measurement of Spare Part Essentiality Criteria

\begin{tabular}{|c|c|c|}
\hline No & Criteria & Mode of quantification \\
\hline 1 & $\begin{array}{l}\text { Original Equipment } \\
\text { Manufacturer (OEM's) } \\
\text { essentiality code }\end{array}$ & $\begin{array}{ll}\text { - } & \text { Vital: NO GO, GO IF MEL A (1 day) } \\
\text { - } & \text { Essential: GO IF MEL B, C, D } \\
\text { - } & \text { Desirable: GO } \\
\end{array}$ \\
\hline 2 & $\begin{array}{l}\text { Airline's essentiality - Minimum } \\
\text { Equipment List (MEL) }\end{array}$ & $\begin{array}{ll}- & \text { Vital: NO GO, GO IF MEL A (1 day) } \\
\text { - } & \text { Essential: GO IF MEL B, C, D } \\
- & \text { Desirable: GO } \\
\end{array}$ \\
\hline 3 & Passenger \& crew criticality & $\begin{array}{ll}\text { - } & \text { Vital: NO GO, GO IF MEL A (1 day) } \\
\text { - } & \text { Essential: GO IF MEL B, C, D } \\
\text { - } & \text { Desirable: GO } \\
\end{array}$ \\
\hline
\end{tabular}

The decision diagram of spare part essentiality is shown in Figure 2. First, the OEM's essentiality code is reviewed. Essentiality is the effect on operations when a failure occurs, but the replacement spare part is not available.

If the essentiality is NO GO or GO IF MEL A, the spare part will be directly assigned to the vital category. If the OEM's essentiality is GO IF MEL B but the airline's criticality is NO GO, then the spare part category is vital. If the Master minimum equipment list (MMEL) criticality is GO but the MEL criticality is GO IF MEL C and the passenger and crew criticality is GO IF, then it will fall into the essential category. The results of this decision diagram will be used as a sub-criterion in the complete hierarchy of aircraft spare part 
classification, which is shown in Figure 3. There are three alternatives to the MCDA model:

Vital, Essential or Desirable.

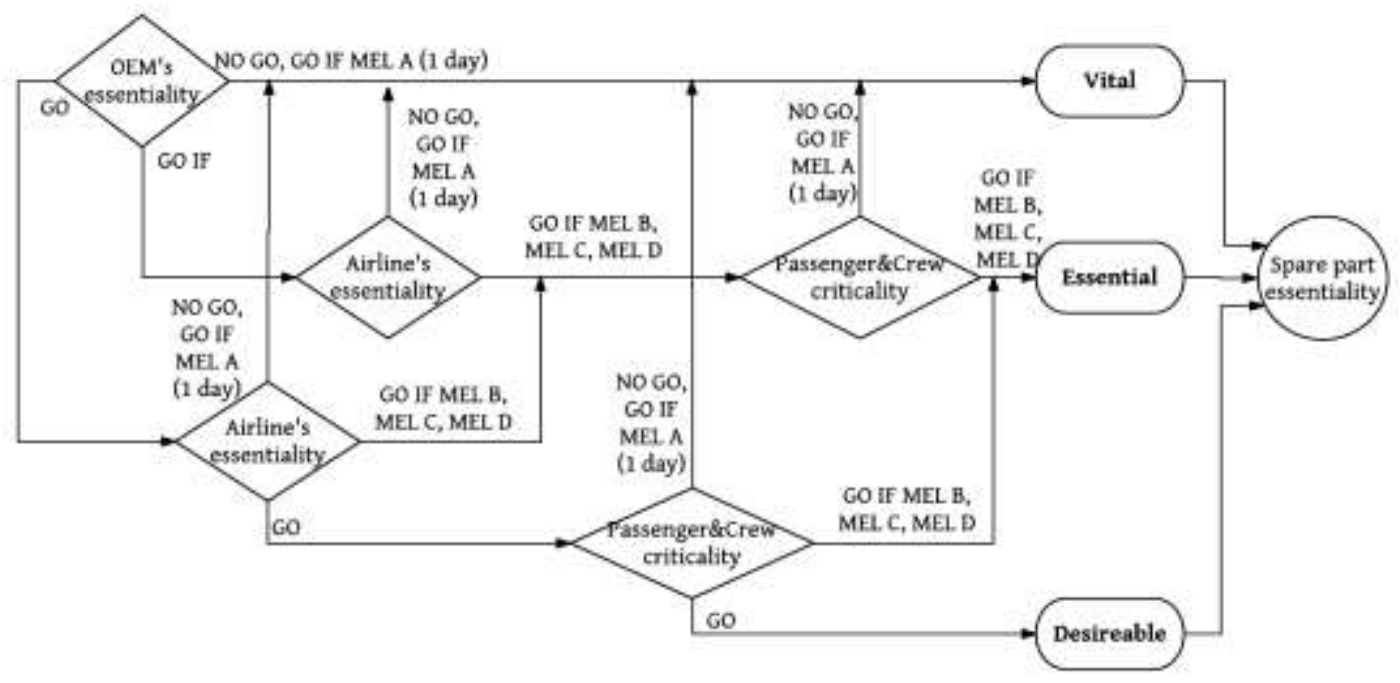

Figure 2 - Decision Diagram of Spare Part Essentiality

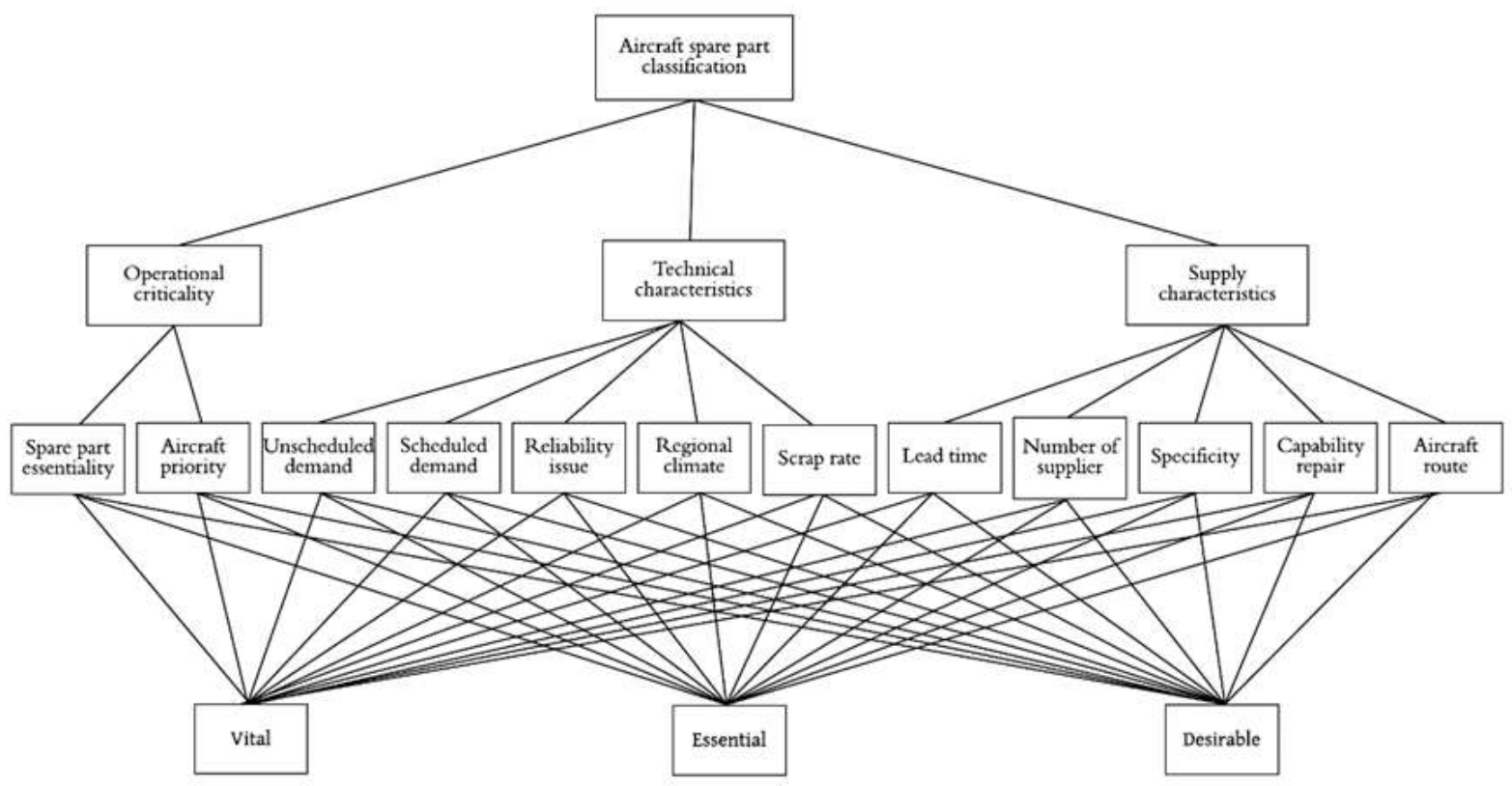

Figure 3 - The Complete Hierarchy for Aircraft Spare Part Classification

In this model, the pairwise ratio is derived from converting the measurement of standard scale into the relative scale (Saaty, 1990). The ratio is obtained from the weights of each criterion using the following equation: 
$\frac{W_{i}}{W_{j}}=a_{i j} \quad($ for $\mathrm{i}, \mathrm{j}=1,2, \ldots \mathrm{n})$

where $\mathrm{a}_{\mathrm{ij}}$ is judgment and $\mathrm{w}_{\mathrm{i}}$ is weight (Saaty, 1980). Table 6 shows the AHP judgement matrix for the three criteria.

Table 6 - AHP Judgement Matrix for Level 1, Aircraft Spare Part Classification

\begin{tabular}{|l|c|c|c|c|}
\hline $\begin{array}{l}\text { Aircraft spare part } \\
\text { classification }\end{array}$ & $\begin{array}{l}\text { Operational } \\
\text { criticality }\end{array}$ & $\begin{array}{l}\text { Technical } \\
\text { characteristics }\end{array}$ & $\begin{array}{l}\text { Supply } \\
\text { characteristics }\end{array}$ & $\begin{array}{l}\text { Normalised } \\
\text { eigenvector }\end{array}$ \\
\hline $\begin{array}{l}\text { Operational } \\
\text { criticality }\end{array}$ & 1 & 1 & 4.692 & 0.452 \\
\hline $\begin{array}{l}\text { Technical } \\
\text { characteristics }\end{array}$ & 1 & 1 & 4.692 & 0.452 \\
\hline $\begin{array}{l}\text { Supply } \\
\text { characteristics }\end{array}$ & 0.213 & 0.213 & 1 & 0.096 \\
\hline$\lambda$ max = 3, C.I. $=$ 0, C.R. $=0$ & & & \\
\hline
\end{tabular}

The next step is to compare the elements of each criterion among themselves. First, the sub-criteria of 'Operational Criticality' are compared. The spare part essentiality was classified previously, resulting in three categories, vital, essential, and desirable. Based on the qualitative data collection, the categorical measurement for each criterion is presented in Table 7. Further, Table 8 presents the AHP judgements of the operational criticality subcriteria. Because the 'Operational Criticality' eigenvector is 0.452 , the eigenvector for spare part essentiality and aircraft criticality are, respectively, 0.334 and 0.118 . The composite weights are computed by multiplying the relative weights of the attributes by those of the alternatives. Based on the composite weight, the upper and lower limit of each alternative for the 'operational criticality' criteria are defined as shown in Table 9. For example, if the spare part essentiality is desirable but the aircraft criticality is essential, the operational criticality is desirable. 
Table 7 - Categorical Measurement of Operational Criticality

\begin{tabular}{|l|l|ll|}
\hline No & \multicolumn{1}{|c|}{ Criteria } & \multicolumn{1}{c|}{ Mode of quantification } \\
\hline 1 & Spare part essentiality & - & Vital: Vital \\
& & - & Essential: Essential \\
& & - & Desirable: Desirable \\
\hline 2 & Aircraft criticality & - & Vital: Wide body \\
& & - & Essential: Narrow body \\
& & - & Desirable: Feeder jet \\
\hline
\end{tabular}

Table 8 - AHP Judgement Matrix for Level 2, Operational Criticality

\begin{tabular}{|l|l|l|l|}
\hline \multicolumn{1}{|c|}{ Criteria } & $\begin{array}{c}\text { Spare part } \\
\text { essentiality }\end{array}$ & \multicolumn{1}{|c|}{$\begin{array}{c}\text { Aircraft } \\
\text { criticality }\end{array}$} & \multicolumn{1}{|c|}{ Normalised eigenvector } \\
\hline $\begin{array}{l}\text { Spare part } \\
\text { essentiality }\end{array}$ & 1.000 & 2.826 & 0.739 \\
\hline Aircraft criticality & 0.354 & 1.000 & 0.261 \\
\hline$\lambda \max =2$, C.I. $=$ 0, C.R. $=0$ & \multicolumn{3}{|l}{} \\
\hline
\end{tabular}

Table 9 - Composite Weights for Operational Criticality

\begin{tabular}{|l|l|l|l|l|}
\hline \multicolumn{1}{|c|}{$\begin{array}{c}\text { Operational } \\
\text { criticality }\end{array}$} & \multicolumn{1}{|c|}{$\begin{array}{c}\text { Spare part } \\
\text { essentiality }\end{array}$} & $\begin{array}{c}\text { Aircraft } \\
\text { criticality }\end{array}$ & \multicolumn{1}{c|}{ Total } & $\begin{array}{c}\text { Classification } \\
\text { boundary }\end{array}$ \\
\hline Vital & 0.216 & 0.077 & 0.293 & $0.154-0.293$ \\
\hline Essential & 0.077 & 0.027 & 0.104 & $0.092-0.153$ \\
\hline Desirable & 0.041 & 0.014 & 0.055 & $0.055-0.091$ \\
\hline
\end{tabular}

Second, the sub-criteria of 'Technical Characteristics' are compared. Based on the qualitative data collection, the categorical measurement for each criterion is presented in Table 10. Further, Table 11 presents the AHP judgements for the 'Technical Characteristic's' sub-criteria. The 'Technical Characteristics' eigenvector is 0.452 , and the eigenvectors for unscheduled demand, reliability issues, regional climate, scheduled demand, and scrap rate are, respectively, 0.156, 0.128, 0.084, 0.052, and 0.03. Based on the composite weight, the upper and lower limits of each alternative of technical characteristics are defined in Table 12 and 13 . 
Table 10 - Categorical Measurement of Technical Characteristics

\begin{tabular}{|c|c|c|}
\hline No & Criteria & Mode of quantification \\
\hline 1 & Unscheduled demand & $\begin{array}{ll}- & \text { Vital: }>5 \\
- & \text { Essential: } 0.5-5 \\
- & \text { Desirable: }<0.5\end{array}$ \\
\hline 2 & Reliability issue & $\begin{array}{ll}\text { - } & \text { Vital: worldwide and regional issue on specific } \\
\text { part number } \\
\text { - } \\
\text { - } \\
\text { Essential: reliability issue on other aircraft type } \\
\text { Desirable: no reliability issue }\end{array}$ \\
\hline 3 & Regional climate & $\begin{array}{ll}\text { - } & \text { Vital: directly affected by regional climate } \\
\text { - } & \text { Essential: maybe affected by regional climate } \\
\text { - } & \text { Desirable: not affected by regional climate }\end{array}$ \\
\hline 4 & Scheduled demand & $\begin{array}{ll}- & \text { Vital: }>5 \\
\text { - } & \text { Essential: } 0.5-5 \\
\text { - } & \text { Desirable: }<0.5 \\
\end{array}$ \\
\hline 5 & Scrap rate & $\begin{array}{ll}\text { - } & \text { Vital: }>75 \% \\
\text { - } & \text { Essential: } 25-75 \% \\
\text { - } & \text { Desirable: }<25 \%\end{array}$ \\
\hline
\end{tabular}

Table 11 - AHP Judgement Matrix for Level 2, Technical Characteristics

\begin{tabular}{|l|l|l|l|l|l|l|}
\hline & $\begin{array}{l}\text { Unscheduled } \\
\text { demand }\end{array}$ & $\begin{array}{l}\text { Reliability } \\
\text { Issue }\end{array}$ & $\begin{array}{l}\text { Regional } \\
\text { Climate }\end{array}$ & $\begin{array}{l}\text { Scheduled } \\
\text { Demand }\end{array}$ & $\begin{array}{l}\text { Scrap } \\
\text { rate }\end{array}$ & $\begin{array}{l}\text { Normalise } \\
\text { eigenvector }\end{array}$ \\
\hline $\begin{array}{l}\text { Unscheduled } \\
\text { demand }\end{array}$ & 1.000 & 1.213 & 1.839 & 3.000 & 5.182 & 0.345 \\
\hline $\begin{array}{l}\text { Reliability } \\
\text { Issue }\end{array}$ & 0.825 & 1.000 & 1.516 & 2.474 & 4.273 & 0.285 \\
\hline $\begin{array}{l}\text { Regional } \\
\text { Climate }\end{array}$ & 0.544 & 0.660 & 1.000 & 1.632 & 2.818 & 0.188 \\
\hline $\begin{array}{l}\text { Scheduled } \\
\text { Demand }\end{array}$ & 0.333 & 0.404 & 0.613 & 1.000 & 1.727 & 0.115 \\
\hline $\begin{array}{l}\text { Scrap rate } \\
\lambda \text { max = 5, C.I. }=0, \text { C.R. }=0\end{array}$ & 0.193 & 0.234 & 0.355 & 0.579 & 1.000 & 0.067 \\
\hline
\end{tabular}


Table 12 - Composite Weights for Technical Characteristics (Part A)

\begin{tabular}{|l|l|l|l|}
\hline $\begin{array}{l}\text { Technical } \\
\text { characteristics }\end{array}$ & $\begin{array}{l}\text { Unscheduled } \\
\text { demand }\end{array}$ & $\begin{array}{l}\text { Reliability } \\
\text { Issue }\end{array}$ & $\begin{array}{l}\text { Regional } \\
\text { Climate }\end{array}$ \\
\hline Vital & 0.101 & 0.095 & 0.056 \\
\hline Essential & 0.036 & 0.022 & 0.022 \\
\hline Desirable & 0.019 & 0.012 & 0.007 \\
\hline
\end{tabular}

Table 13 - Composite Weights for Technical Characteristics (Part B)

\begin{tabular}{|l|l|l|l|l|}
\hline $\begin{array}{l}\text { Technical } \\
\text { characteristics }\end{array}$ & $\begin{array}{l}\text { Scheduled } \\
\text { Demand }\end{array}$ & Scrap rate & Total & $\begin{array}{l}\text { Classification } \\
\text { boundary } \\
\text { (Lower/Upper) }\end{array}$ \\
\hline Vital & 0.034 & 0.020 & 0.305 & $0.166-0.305$ \\
\hline Essential & 0.012 & 0.007 & 0.099 & $0.073-0.166$ \\
\hline Desirable & 0.006 & 0.004 & 0.048 & $0.048-0.072$ \\
\hline
\end{tabular}

Third, the sub-criteria of 'Supply Characteristics' are compared. Based on the qualitative data collection, the categorical measurement for each criterion is presented in Table 14. Further, Table 15 presents the AHP judgements of the supply characteristics subcriteria. Because the supply characteristics eigenvector is 0.096 , the eigenvector for lead time, aircraft route, number of supplier, specificity, and capability of repair are, respectively, 0.036 , $0.017,0.020,0.011$, and 0.011 . Based on the composite weight, the upper and lower limit of each alternative of supply characteristics are defined in Table 16 and 17. 
Table 14 - Categorical Measurement of Supply Characteristics

\begin{tabular}{|c|c|c|}
\hline No & Criteria & Mode of quantification \\
\hline 1 & Lead time & $\begin{array}{ll}\text { - } & \text { Vital: }>20 \text { days } \\
\text { - } & \text { Essential: } 1-20 \text { days } \\
\text { - } & \text { Desirable: }<24 \text { hours }\end{array}$ \\
\hline 2 & Aircraft route & $\begin{array}{ll}\text { - } & \text { Vital: point to point } \\
\text { - } & \text { Essential: hub and spoke } \\
\text { - } & \text { Desirable: long haul } \\
\end{array}$ \\
\hline 3 & Number of supplier & $\begin{array}{ll} & \text { Vital: } 1 \\
- & \text { Essential: } 1-5 \\
- & \text { Desirable: }>5 \\
\end{array}$ \\
\hline 4 & Specificity & $\begin{array}{l}\text { - Vital: peculiar part number of rare aircraft type } \\
\text { - Essential: peculiar part number of common aircraft } \\
\text { type } \\
\text { - Desirable: common part number in several aircraft } \\
\text { type }\end{array}$ \\
\hline 5 & Capability repair & $\begin{array}{ll}\text { - } & \text { Vital: inhouse capability repair } \\
\text { - } & \text { Essential: inhouse capability test } \\
\text { - } & \text { Desirable: no capability } \\
\end{array}$ \\
\hline
\end{tabular}

Table 15 - AHP Judgement Matrix for Level 2, Supply Characteristics

\begin{tabular}{|c|c|c|c|c|c|c|}
\hline & $\begin{array}{l}\text { Lead } \\
\text { time }\end{array}$ & $\begin{array}{l}\text { Aircraft } \\
\text { route }\end{array}$ & $\begin{array}{l}\begin{array}{l}\text { Number } \\
\text { of } \\
\text { suppliers }\end{array} \\
\end{array}$ & Specificity & $\begin{array}{l}\text { Capability } \\
\text { of repair }\end{array}$ & $\begin{array}{l}\text { Normalised } \\
\text { eigenvector }\end{array}$ \\
\hline Lead time & 1.000 & 2.161 & 1.811 & 3.190 & 3.190 & 0.379 \\
\hline $\begin{array}{l}\text { Aircraft } \\
\text { route }\end{array}$ & 0.463 & 1.000 & 0.838 & 1.476 & 1.476 & 0.175 \\
\hline $\begin{array}{l}\text { Number of } \\
\text { suppliers }\end{array}$ & 0.552 & 1.194 & 1.000 & 1.762 & 1.762 & 0.209 \\
\hline Specificity & 0.313 & 0.677 & 0.568 & 1.000 & 1.000 & 0.119 \\
\hline $\begin{array}{l}\text { Capability } \\
\text { of repair }\end{array}$ & 0.313 & 0.677 & 0.568 & 1.000 & 1.000 & 0.119 \\
\hline
\end{tabular}

Table 16 - Composite Weights for Supply Characteristics (Part A)

\begin{tabular}{|l|l|l|l|}
\hline $\begin{array}{l}\text { Supply } \\
\text { characteristics }\end{array}$ & Lead time & Aircraft route & Number of supplier \\
\hline Vital & 0.027 & 0.012 & 0.015 \\
\hline Essential & 0.006 & 0.003 & 0.003 \\
\hline Desirable & 0.003 & 0.002 & 0.002 \\
\hline
\end{tabular}


Table 17 - Composite Weights for Supply Characteristics (Part B)

\begin{tabular}{|l|l|l|l|l|}
\hline $\begin{array}{l}\text { Supply } \\
\text { characteristics }\end{array}$ & Specificity & $\begin{array}{l}\text { Capability } \\
\text { repair }\end{array}$ & Total & $\begin{array}{l}\text { Classification } \\
\text { boundary } \\
\text { (lower/upper) }\end{array}$ \\
\hline Vital & 0.009 & 0.008 & 0.071 & $0.038-0.071$ \\
\hline Essential & 0.002 & 0.002 & 0.016 & $0.014-0.037$ \\
\hline Desirable & 0.001 & 0.001 & 0.008 & $0.008-0.013$ \\
\hline
\end{tabular}

\subsubsection{Aircraft Spare Part Inventory Assignment and Decision}

Based on the data collected during the interviews, three main inventory strategy decisions emerged: i) stock, ii) JIT delivery, and iii) no stock. Therefore, the adequate inventory strategy is to stock the vital category, design a JIT delivery system for the essential category, and don't hold any stock for the desirable category.

\subsection{The effectiveness of multi-criteria inventory classification model to the traditional method of inventory management}

To test the effectiveness and validity of this model, a classification test was conducted. A total of 1267 part numbers of rotable B737NG spare parts characteristics data ranging from the quantitative data such as, scheduled demand, unscheduled demand and lead time, to the qualitative data such as, reliability issue, regional climate, and passenger related criticality, are extracted from the system to evaluate the effectiveness and accuracy of this multi-criteria inventory classification model using AHP. The part numbers are examined and compared to the current mathematical method of inventory management, its adjusted version and the actual stock.

Rotable spare parts are chosen for the study because it requires more engineering adjustment than the consumable parts. The B737NG aircraft type was chosen because it is a mature aircraft type in the company. Therefore, a complete spare parts characteristics data was available.

The results are compared with the current practices, which consists of the mathematical model and the expert judgement. As mentioned by the respondents, "first, the spare part quantity is calculated using a mathematical model. Then, it is adjusted with the expert judgement, as we cannot fully rely on the calculation”. The results are also compared with the actual stock, as shown in Table 18. 
Table 18 - Results Comparison

\begin{tabular}{|c|c|c|c|c|c|c|}
\hline \multirow{2}{*}{\multicolumn{2}{|c|}{ Method }} & \multicolumn{3}{|c|}{ Total part number } & \multirow[b]{2}{*}{$\begin{array}{l}\text { Similar } \\
\text { outcome }\end{array}$} & \multirow[b]{2}{*}{ Accuracy } \\
\hline & & $\begin{array}{l}\text { Vital = } \\
\text { Stock }\end{array}$ & $\begin{array}{l}\text { Essential } \\
=\text { JIT } \\
\text { Delivery }\end{array}$ & $\begin{array}{l}\text { Desirable } \\
=\text { No } \\
\text { Stock }\end{array}$ & & \\
\hline $\mathrm{AHP} \mathrm{cl}$ & sification model & 482 & 681 & 104 & & \\
\hline \multirow{3}{*}{$\begin{array}{l}\text { Current } \\
\text { practice }\end{array}$} & $\begin{array}{l}\text { Mathematical } \\
\text { model }\end{array}$ & 490 & 575 & 202 & 1021 & $80.6 \%$ \\
\hline & $\begin{array}{l}\text { Mathematical and } \\
\text { engineering } \\
\text { adjustment }\end{array}$ & 513 & 651 & 103 & 1236 & $97.6 \%$ \\
\hline & Current stock & 473 & 550 & 244 & 807 & $63.7 \%$ \\
\hline
\end{tabular}

These findings suggest that i) AHP lead to a transparent and systematic classification model mimicing the decision maker cognitive process ii) the classification model is highly accurate and precise with an outcome comparable to the traditional and up to $97.6 \%$ similarities with the adjusted model, which is considered the optimum option, but might be difficult in practice and can lack transparency and consistency.

\section{Discussion}

\subsection{RQ1: What are the criteria and sub-criteria to be considered to develop a relevant} MCDA model for an aircraft spare part classification system?

It was found that each stakeholder group have similar preferences regarding relevant criteria. Two thirds of the airline and supply stakeholders prefer 'operational criticality' as the most important criteria, while all technical decision-makers chose 'technical characteristics' as the most important criteria. It was also shown that there are particular criteria which are only mentioned by a specific stakeholder group. For example, aircraft priority as a part of 'operational criticality' was only mentioned by the operational stakeholder or airlines. Scrap rate as a part of the 'technical characteristic' was only mentioned by the technical department decision-makers. Specificity, which is a part of the 'supply characteristics', was only mentioned by the material department and the supply stakeholders. This demonstrates the lack of holistic organisational perspective that can be built in a traditional decision making system and that MCDA is a powerful modelling technique overcoming this issue. These findings are in line with Trutnevyte et al., (2012) and Lolli et al., (2014). It is also consistent with von Winterfeldt et al., (2009) study, which takes into account each stakeholders concern in structuring decision problem, recognising that all decision-makers have different view point and they should be considered to reach an optimum solution. 
Regarding the criteria, the study shows that both 'operational criticality' and 'technical characteristics' had the same weight of 6.8 , there are considered to be the prominent criteria, while the 'supply characteristics' criteria is considered to have only a marginal effect on the inventory classification. In the literature of spare part classification in the context of manufacturing industry, it was found that the most important criteria is the 'operational criticality' (Cakir and Canbolat, 2008; Roda et al., 2014). In contrast, in the aviation industry, the 'technical characteristics' have the highest importance $(\operatorname{Rad}$ et al., 2011; Wang and Kang 2007). However, both of these studies did not consider 'operational criticality. Nevertheless, Braglia et al., (2004) and Molenaers et al., (2012) agree and suggest to consider it as the most important factor.

In term of 'operational criticality', the findings indicate that there are two relevant sub-criteria, spare part essentiality and aircraft criticality. It is evident that spare part essentiality is related to the consequences for operations when a failure occurs, but the replacement spare part is not in stock, which is similar to Huiskonen's (2001) definition. Spare part essentiality was found to be the most important criterion with the highest weight in several studies (Cakir and Canbolat; 2008; Flores and Whybark, 1987). Though some spare part classification studies do not include spare part essentiality as a criterion $(\mathrm{Ng}, 2007$; Wang and Kang, 2007; Hadi-Vencheh 2011; Rad et al., 2011), Roda et al., (2012) find that a $100 \%$ of surveyed companies use this criterion to classify spare part criticality. Therefore, spare part essentiality is relevant to consider in spare part inventory classification.

In their study, Roda et al., (2014) also found that spare part essentiality in the manufacturing industry is rather difficult to measure in monetary terms. In contrast, Driessen et al., (2015) propose an essentiality measurement based on the type of breakdown. Stockout parts that cause full breakdown of the system are full critical, and parts that cause no breakdown are not critical. This measurement system is rather ambiguous. In the highly regulated aircraft industry (Regattieri et al., 2015), the measurement of spare part essentiality is clear. Spare part essentiality is measured by the time in which failure has to be corrected, which is similar to Huiskonen's (2001) arguments about the degree of criticality. In aircraft spare parts, there are three degrees of essentiality that can be determined: i) failure that has to be corrected and the spare has to be supplied immediately, or NO GO, ii) failure that can be rectified in a short period, or GO IF, and iii) failure that is not critical to the operation of aircraft, or GO. This can be adjusted with the airline's MEL category, which may vary from operator to operator and expert judgement on passenger and crew criticality if necessary (Kinnison and Siddiqui, 2013). 
In the aviation industry, another criterion affecting operational criticality is aircraft priority. This is related to the cost consequence when the aircraft is grounded. The findings show that every aircraft type has a different cost consequence depending on the number of passengers and the destination, which is similar to Dekker et al.'s (1998) perspective of machine criticality in the manufacturing industry. Although this sub-criterion has less weight than the previous one, many authors consider aircraft or machine criticality in their classification (Gajpal, 1994; Braglia et al., 2004; Stoll et al., 2015).

Regarding the 'technical characteristics', five criteria were found: unscheduled demand, scheduled demand, reliability issues, regional climate, and scrap rate. In the literature, the most important technical characteristic is the annual demand (Braglia, 2004; Cavalieri, 2008; Roda et al., 2011; Rezaei and Dowlatshahi, 2010). However, the findings show that it is important to divide the unscheduled demand and scheduled demand, similar to Huiskonen's (2001) and Perssona and Saccani (2008) argument about demand predictability. This unscheduled maintenance typically emerges during inspections carried out as a part of condition-based maintenance, which has considerable implications for inventory management (Samaranayake, 2012). Therefore, unscheduled demand is the most important criterion under technical characteristics. The second important criterion is reliability issues, which is also found in more recent spare part classification literature (Baykasoglu et al., 2016; Driessen et $a l ., 2015)$. The reliability issue criterion is related to durability problems that occur in components that might adversely affect the airline. The next one is the regional climate, which is also mentioned by Kinnison and Siddiqui (2014), as the component stocking strategy differs from airline to airline because it is determined by the flight environment. This criterion is peculiar to the transportation industry. The least important criterion found in this study is the scrap rate. Although this criterion does not appear in many studies, Cavalieri et al. (2008) and Driessen et al. (2015) consider this criterion to determine optimun inventory strategies.

The 'supply characteristics' are considered the least important criteria compared to 'operational criticality' and 'technical characteristics', which is similar to Cakir and Canbolat's (2008) criteria weighting. This is because there have been several cooperative strategies among aviation players (Kilpi et al., 2009), which provides more certainty in supply continuity. However, some supply problems still arise because of long repair Turn Around Time (TAT) on some components and the number of suppliers, especially for rare types of aircraft. Lead time is considered the most important criterion of the supply characteristics, with a weight of 7.44. It is supported by the evidence that most of the 
literature use lead time as criteria (as per Table 1). Number of suppliers and aircraft route are considered the very important as they relate to the distribution. An extensive literature search shows that aircraft route is also used in aircraft inventory optimisation model (Sun and Zuo, 2010). The next criterion is specificity, which is mentioned in Huiskonen (2001), Braglia (2004), and Cakir and Canbolat (2008) studies. The evidence also shows capability repair as a factor affecting the inventory decision which is consistent with Driessen et al. (2015) suggestion about internal repair capability determine the supply sources.

\subsection{RQ2: To what extent is AHP a practical and effective solution as a multi-criteria spare part classification system against the traditional methods?}

Weighted linear optimisation model, as used by Ng (2007) and Zhou and Fan (2007), usually only consider quantitative criteria namely price, lead time and demand. The qualitative criteria such as spare part essentiality, specificity and reliability cannot be well considered in the mathematical modelling. Therefore, the current mathematical decision-making model does not represent a holistic thinking of the decision-makers. However, AHP allows considering both quantitative and qualitative criteria in the classification, it enables the multicriteria classification of the spare part, in line with Gajpal et al., (1994) Lolli et al., (2014) Stoll et al., (2015) Subramanian and Ramanathan (2012) .

AHP has ability to structure and cluster all factors in a hierarchical manner to deal with the complex nature of a problem (Naesens et al., 2009; Subramanian and Ramanathan, 2012). As shown in the findings and literature review sections, inventory strategy selection for aircraft spare part is a complex decision-making problem due to the stockout cost and their implications (Erkoc and Ertogal, 2016), the stringent regulation (Vieira and Loures, 2016), the spare part price (de Souza et al., 2011), the long lead time and the unscheduled removal (Wang and Yue, 2015), hence is a good candidate to test AHP solutions. Unlike other decision-making method, AHP can cope with the complexity of the problem thanks to its hierarchical structure and its pairwise comparison concept (Saaty, 2008). In this research, all factors affecting aircraft spare part inventory strategy selection are investigated and clustered into three criteria and 12 sub-criteria. It was found that the clustering process made the decision-makers think more realistically and holistically about the problem and iron out some misconceptions (Dehe and Bamford, 2015). For example, during the investigation, many participants stated that lead time was the most important criteria in the first instance. However, going through the AHP process, lead time become a sub-criteria of the 'supply characteristics', the least important criteria of the model. 
The third aspect is the ability of AHP to be a transparent, easy and user-friendly classification model. The AHP classification model enables the decision-makers to structure the criteria and define the categorical measurement and composite weight, which facilitates transparency for all stakeholders (Molenaers et al., 2012). Especially in the aviation industry, where the spare part price is very costly (de Souza et al., 2011), transparency in inventory decision-making is imperative. The classification model was developed with Microsoft Excel, so users could easily use it and the inventory solution is automatically computed.

The effectiveness of a decision support can be measured by comparing its output to other methods using the same inventory data (Cakir and Canbolat, 2008). This argument supports the findings which compare AHP classification method to the current practices to test the effectiveness of the model. It is apparent from the finding (Table 17) that the multicriteria inventory management classification developed in this research is consistent with the other computing methods.

First, the results between AHP model and the current method of classification with only mathematical modelling are compared. This method contains only quantitative calculation. The findings show that the practitioners cannot fully rely on the calculation because it considers only quantitative criteria. Table 19 compares the result of AHP model with the mathematical model. The total similarity is of $80.6 \%$, which is considered to be moderately consistent. There are 246 part numbers deviations, which are found in stock, JIT delivery and no stock category. It is further analysed on the 18 spare part JIT delivery and 93 no stock based on the mathematical model. It is found that all the part numbers have vital category essentiality (No Go and Go If A) and most of them have high unscheduled removal rate and global reliability issue. The unavailability of those part numbers will cause significant operational problems. Therefore, it is better to put those part numbers on stock rather than on JIT delivery and no stock.

Table 19 - Comparison between AHP model to Math Model 


\begin{tabular}{|c|c|c|c|c|}
\hline \multirow[t]{2}{*}{ Math Model } & \multicolumn{3}{|c|}{ AHP } & \multirow[b]{2}{*}{ Total Math Model } \\
\hline & $\begin{array}{l}\text { Vital } \\
= \\
\text { Stock }\end{array}$ & $\begin{array}{l}\text { Essential = JIT } \\
\text { delivery }\end{array}$ & $\begin{array}{l}\text { Desirable } \\
=\text { No } \\
\text { Stock }\end{array}$ & \\
\hline Vital $=$ Stock & 371 & 108 & 11 & 490 \\
\hline Essential = JIT delivery & 18 & 557 & 0 & 575 \\
\hline Desirable $=$ No Stock & 93 & 16 & 93 & 202 \\
\hline Total AHP & 482 & 681 & 104 & \\
\hline
\end{tabular}

Second, the results between AHP model and the current approach of classification with mathematical modelling and engineering adjustment are compared. This method contains quantitative calculation and qualitative adjustment from engineering. However, it is not considered to be a transparent or consistent process. Morevoer, there is no formal structure for the required type of qualitative adjustment to be made on a specific spare part. The adjustment is decided by the experts are based on their experience. The result of AHP model compared to the mathematical model and engineering adjustment method is shown in Table 20. The total similar outcome between these methods is 1236 out of the 1267 part numbers or $97.6 \%$, which is considered to be highly consistent. There are 31 part numbers deviations which are found in JIT delivery and no stock category. It is further analysed that most of the deviation part numbers have essential or desirable 'operational criticality' and 'technical characteristics', which caused unnecessary investment in 31 non-critical components.

Table 20 - Comparison between AHP model to Math Model and Engineering Adjustment Method

\begin{tabular}{|c|c|c|c|c|}
\hline \multirow{2}{*}{$\begin{array}{l}\text { Math Model and } \\
\text { Engineering } \\
\text { Adjustment }\end{array}$} & \multicolumn{3}{|c|}{ AHP } & \multirow[b]{2}{*}{$\begin{array}{l}\text { Total Math Model and } \\
\text { Eng. Adjust. }\end{array}$} \\
\hline & $\begin{array}{l}\text { Vital } \\
= \\
\text { Stock }\end{array}$ & $\begin{array}{l}\text { Essential = JIT } \\
\text { delivery }\end{array}$ & $\begin{array}{l}\text { Desirable } \\
=\text { No Stock }\end{array}$ & \\
\hline Vital = Stock & 482 & 30 & 1 & 513 \\
\hline Essential = JIT delivery & 0 & 651 & 0 & 651 \\
\hline Desirable $=$ No Stock & 0 & 0 & 103 & 103 \\
\hline Total AHP & 482 & 681 & 104 & \\
\hline
\end{tabular}

Finally, the results between AHP model and the current stock are compared. From the findings, it is apparent that the company held more than USD 100 million stock value with $71 \%$ of rotable spare parts have been static for the past six months. Despite the fact that most of the spare part unmoved in the last six months, the findings show that there still some spare 
part stock out problems, causing costly flight delay and cancellation. In Table 21, the AHP results are compared. The total similar outcome between these methods is 807 part numbers or $63.7 \%$, which is considered to be an acceptable consistency. The deviation is mostly located on the no stock item, where 179 part number have no stock, but it is considered as stock and JIT delivery with the AHP model. Further analysis found that most of the current no stock parts have vital and essential category essentiality and high unscheduled removal. This caused operational flight disruptions. Other 146 current on stock part numbers mostly have low demand, causing unmoved inventory.

Table 21 - Comparison between AHP model to Current Stock

\begin{tabular}{|l|l|l|l|l|}
\hline \multirow{2}{*}{ Current Stock } & AHP & \multirow{2}{*}{} \\
\cline { 2 - 4 } & $\begin{array}{l}\text { Vital } \\
=\text { Stock }\end{array}$ & $\begin{array}{l}\text { Essential = JIT } \\
\text { delivery }\end{array}$ & $\begin{array}{l}\text { Desirable } \\
=\text { No Stock }\end{array}$ & Total Current Stock \\
\hline Vital =Stock & 327 & 144 & 2 & 473 \\
\hline $\begin{array}{l}\text { Essential = JIT } \\
\text { delivery }\end{array}$ & 98 & 415 & 37 & 550 \\
\hline Desirable = No Stock & 57 & 122 & 65 & 244 \\
\hline Total AHP & 482 & 681 & 104 & \\
\hline Total Similar Outcome $=807(63.7 \%)$ & \\
\hline
\end{tabular}

Therefore, this demonstrates that the AHP classification model is proven to be overall more effective compared to current methods in practice and constitute the contribution of this paper.

\section{Conclusions}

This empirical study enabled to develop a MCDA model composed on 3 criteria and 12 subcriteria to enhance aircraft spare part classification process within an MRO firm. The relevant identified criteria are i) 'operational criticality' which consist of spare part essentiality and aircraft criticality, ii) 'technical characteristics' which consists of unscheduled demand, reliability issues, regional climate, scheduled demand, and scrap rate, and iii) 'supply characteristics' which consists of lead time, aircraft route, number of suppliers, specificity, and capability of repair. It is noteworthy to emphasise that in the aviation industry, both 'operational criticality' and 'technical characteristics' are suggested to be the most important criteria due to the stringent regulation imposed to ensure passenger safety (Vieira and Loures, 2016), while 'supply characteristics' is considered to be less important and moderated by the collaborative strategies among the aviation partners, which lead to an incresed certainty in the supply continuity (Kilpi et al., 2009). 
The developed AHP model enabled a practical and relevant multi-criteria classification of aircraft spare part thanks to its ability to i) aggregate both qualitative and quantitative criteria (Stoll et al., 2015), ii) structure and cluster all factors in hierarchical manner (Saaty, 2008; Saaty, 1990), iii) enable different weight in each criterion to be considered, iv) provide a transparent (Molenaers et al, 2012) and user friendly decisionmaking framework (Roda et al., 2014) and v) integrate the decision diagram logic to solve the specific aircraft spare part essentiality classification.

Moreover, this AHP classification is proven to be highly accurate, as its output is consistent with the most precise current methods: mathematical model adjusted with the expert judgement. A similarity of $97.6 \%$ led the case company to be confident in its effectiveness and validity and is considering implementing this technique in the future to optimise its spare part inventory strategy.

From a practical contribution, the research has enabled the development of an AHP model which is more transparent and more effective than the current practices, in order to solve complex aircraft spare part classification decision-making problems and their associated inventory strategy. Moreover, from a theoretical contribution, the study enabled to consolidate the current body of knowledge on application of MCDA as a spare part optimisation framework, as well as contributing to the development of multi-criteria inventory classification literature in the aviation industry, which remains rather under represented compared to the manufacturing sector.

We believe that this research can also be used as the foundation for future research in the optimisation of other material management strategies, including replenishment and allocation strategies, using MCDA and AHP.

Howeverwe identify four limitations. First, a single case study is deployed in this research, which prevents the wider generalizability of the findings; nonetheless, if the models suitability is confirmed by future case studies the generalisation could lead to a substantial contribution, in term of enhancing the role and strength of MCDA as the optimum solution to inventory classification problems. Second, the subjective and the sensitive nature of the AHP method must be recognised and acknowledged. However, in this study, this limitation was controlled and moderated by the high level of consistency found between the outcomes of the different methods. We can conclude that the AHP model is well calibrated for this study. Thirdly, AHP cannot be used as a sequential decision-making tool to classify the essentiality of a spare part. According to the findings, evaluating spare parts 'essentiality' will need to be done sequentially from the OEM's spare part 'essentiality', the airline's spare part 
'essentiality' (MEL) to the passenger and crew criticality. Finally, the data collection relied primarily on semi-structured interviews, where the interactions between the different decision-makers were made indirectly via the interviewee. It might be relevant to validate further the model, the weighting and the assessment using focus group where the results are generated from the direct interactions between the decision-makers or via a Delphi method.

\section{References}

Ahsan, K. \& Rahman, S., 2016. An investigation into critical service determinants of customer to business (C2B) type product returns in retail firms. International Journal of Physical Distribution \& Logistics Management, 46(6/7), 606-633.

Al-Kaabi, H., Potter, A.T., Naim, M.M., 2007. An outsourcing decision model for airlines' MRO activities. Journal of Quality in Maintenance Engineering, 13(3), 217-227.

Ayeni, P., Baines, T., Lightfoot, H., Ball, P., 2011. State-of-the-art of "Lean" in the aviation maintenance, repair, and overhaul industry. Proceedings of the Institution of Mechanical Engineers, Part B: journal of engineering manufacture, 2108-2123.

Bacchetti, A., Saccani, N., 2012. Spare parts classification and demand forecasting for stock control: Investigating the gap between research and practice. Omega, 40(6), 722-737.

Baykasoğlu, A., Subulan, K. \& Karaslan, F.S., 2016. A new fuzzy linear assignment method for multi-attribute decision making with an application to spare parts inventory classification. Applied Soft Computing, 42, 1-17.

Bazargan, M., 2015. An optimization approach to aircraft dispatching strategy with maintenance cost - A case study. Journal of Air Transport Management, 42, 10-14.

Braglia, M., Grassi, A. \& Montanari, R., 2004. Multi-attribute classification method for spare parts inventory management. Journal of Quality in Maintenance Engineering, 10(1), $55-65$.

Bryman, A. and Bell, E., 2011. Business research methods, 3rd edition, Oxford: Oxford University Press.

Cakir, O. \& Canbolat, M.S., 2008. A web-based decision support system for multi-criteria inventory classification using fuzzy AHP methodology. Expert Systems with Applications, 35(3), 1367-1378.

Cavalieri, S., Garetti, M., Macchi, M., Pinto, R., 2008. A decision-making framework for managing maintenance spare parts. Production Planning \& Control, 19(4), 379-396.

Chopra, S., Meindl, P., 2016. Supply Chain Management: Strategy, Planning and Operation, $6^{\text {th }}$ edition, Harlow: Pearson Education Limited.

Cohen, M. a., Zheng, Y.-S. \& Agrawal, V., 1997. Service parts logistics: a benchmark analysis. IIE Transactions, 29(8), 627-639.

de Souza, R., Tan, A.W.K., Othman, H., Garg, M., 2011. A proposed framework for managing service parts in automotive and aerospace industries. Benchmarking: An International Journal, 18(6), 769-782.

Dehe, B., Bamford, D., 2015. Development, test and comparison of two Multiple Criteria Decision Analysis (MCDA) models A case of healthcare infrastructure location. Expert Systems with Applications, 42, 6717-6727.

Dekker, R., Kleijn, M.J., De Rooij, P.J., 1998. A spare parts stocking policy based on equipment criticality. International Journal of Production Economics, 56-57, 69-77.

Driessen, M., Arts, J., van Houtum, G., Rustenburg, J.W., Huisman, B., 2015. Maintenance spare parts planning and control: a framework for control and agenda for future research. Production Planning \& Control, 26(5), 407-426. 
Duchessi, P., Tayi, G.K., Levy, J.B., 1988. Approach for Managing of Spare Parts. International Journal of Physical Distribution \& Materials Management, 18(5), 8-15.

Easterby-Smith, M., Thorpe, R., Jackson, P.R., 2008. Management Research: Theory and Practice, London: Sage Publications.

Erkoc, M. \& Ertogral, K., 2016. Overhaul planning and exchange scheduling for maintenance services with rotable inventory and limited processing capacity. Computers \& Industrial Engineering, 98, 30-39.

Falsini, D., Fondi, F., Schiraldi, M.M., 2012. A logistics provider evaluation and selection methodology based on AHP, DEA and linear programming integration. International Journal of Production Research, 50(17), 4822-4829.

Flint, P., 2002. Trying to hold on. Air Transport World 39, 11, 60-63.

Flores, B.E., Whybark, D.C., 1987. Implementing multiple criteria ABC analysis. Journal of Operations Management, 7(1-2), 79-85.

Friend, C.H., 1992. Aircraft Maintenance Management, Longman.

Gajpal, P.P., Ganesh, L.S., Rajendran, C., 1994. Criticality analysis of spare parts using the analytic hierarchy process. International Journal of Production Economics, 35, $293-$ 297.

Gay, W., Bamford, D., 2007. A case study into the management of racial diversity within an NHS teaching hospital, International Journal of Public Sector Management, 20(4), 257 271.

Gomez, A. and Carnero, M.C., 2011. Selection of a computerised maintenance management system: a case study in a regional health service. Production Planning and Control, 22(4), pp.426-436.

Goodwin, P., Wright, G., 1998. Decision analysis for management judgement, $2^{\text {nd }}$ edition, Chichester: John Wiley \& Sons Ltd.

Gu, J., Zhang, G., Li, K.W., 2015. Efficient aircraft spare parts inventory management under demand uncertainty. Journal of Air Transport Management, 42, 101-109.

Hadi-Vencheh, A., Mohamadghasemi, A., 2011. A fuzzy AHP-DEA approach for multiple criteria ABC inventory classification. Expert Systems with Applications, 38(4), 33463352.

Harkonen, J., Haapasalo, H. \& Hanninen, K., 2016. Productisation : A review and research agenda. International Journal of Production Economics, 164, 65-82.

Huiskonen, J., 2001. Maintenance spare parts logistics: Special characteristics and strategic choices. International Journal of Production Economics, 71, 125-133.

IATA, 2015. Airline Maintenance Cost: Executive Commentary., https://www.iata.org/whatwedo/workgroups/Documents/MCTF/AMC-Exec-CommentFY14.pdf

IATA, 2015. Guidance Material and Best Practices for Inventory management., https://www.iata.org/whatwedo/workgroups/Documents/MCTF/inventory-mgmt-2ndedition.pdf

Karsten, F., Basten, R.J.I., 2014. Pooling of spare parts between multiple users: How to share the benefits? European Journal of Operational Research, 233, 94-104.

Kennedy, W.J., Wayne Patterson, J. \& Fredendall, L.D., 2002. An overview of recent literature on spare parts inventories. International Journal of Production Economics, 76, 201-215.

Kilpi, J., Töyli, J. \& Vepsäläinen, A., 2009. Cooperative strategies for the availability service of repairable aircraft components. International Journal of Production Economics, 117, 360-370.

Kilpi, J. \& Vepsäläinen, A.P.J., 2004. Pooling of spare components between airlines. Journal of Air Transport Management, 10, 137-146. 
King, N., (2012), Doing template analysis. In: G.Symon and C.Cassell (Eds.) Qualitative Organizational Research: Core Methods and Current Challenges. London: Sage Publications.

Kinnison, H.A., Siddiqui, T., 2013. Aviation Maintenance Management, $2^{\text {nd }}$ edition, New York: McGraw-Hill

Knotts, R., 1999. Civil aircraft maintenance and support Fault diagnosis from a business perspective. Journal of Quality in Maintenance Engineering, 5(4), 335-348.

Lolli, F., Ishizaka, A., Gamberini, R., 2014. New AHP-based approaches for multi-criteria inventory classification. International Journal of Production Economics, 156, 62-74.

Marais, K.B., Robichaud, M.R., 2012. Analysis of trends in aviation maintenance risk : An empirical approach. Reliability Engineering and System Safety, 106, 104-118.

McDonald, M.M., 2002, Custom tuning, Air Transport World, 48-50.

Molenaers, A., Baets, H., Pintelon, L., Waeyenbergh, G.,, 2012. Criticality classification of spare parts: A case study. International Journal of Production Economics, 140, 570578.

Muckstadt, J.A., 2005. Analysis and Algorithms for Service Part Supply Chains, New York: Springer.

Mukhopadhyay, S.K., Pathak, K., Guddu, K., 2003. Development of decision support system for stock control at area level in mines, Institution of Engineers (India) Journal - Mining $84,1,11-16$

Naesens, K., Gelders, L., Pintelon, L., 2009. A swift response framework for measuring the strategic fit for a horizontal collaborative initiative. International Journal of Production Economics, 121, 550-561.

$\mathrm{Ng}$, W.L., 2007. A simple classifier for multiple criteria ABC analysis. European Journal of Operational Research, 177, 344-353.

Partovi, F.Y., Anandarajan, M., 2002. Classifying inventory using an artificial neural network approach. Computers and Industrial Engineering, 41(4), 389-404

Partovi, F. Y., \& Burton, J. 1993. Using the analytic hierarchy process for ABC analysis. International Journal of Production and Operations Management, 13 (9), 29-44.

Persson, F. and Saccani, N., 2009. Managing the after-sales logistic network-a simulation study. Production Planning and Control, 20(2), pp.125-134.

Rad, T., Shanmugarajan, N., Wahab, M.I.M., 2011. Classification of critical spares for aircraft maintenance. 8th International Conference on Service Systems and Service Management - Proceedings of ICSSSM'11.

Ramanathan, R., 2006. ABC inventory classification with multiple-criteria using weighted linear optimization. Computers and Operations Research, 33(3), 695-700.

Regattieri, A., Giazzi, A., Gamberi, M., Gamberini, R., 2015. An innovative method to optimize the maintenance policies in an aircraft: General framework and case study. Journal of Air Transport Management, 44-45, 8-20.

Rezaei, J. \& Dowlatshahi, S., 2010. A rule-based multi-criteria approach to inventory classification. International Journal of Production Research, 48(23), 7107-7126.

Roda, I., Macchi, M., Fumagalli, L., 2014. A review of multi-criteria classification of spare parts. Journal of Manufacturing Technology Management, 25(4), 528-549.

Saaty, T.L, 1980. The Analytic Hierarchy Process. New York: McGraw-Hill

Saaty, T.L., 1990. How to make a decision: The analytic hierarchy process. European Journal of Operational Research, 48, 9-26.

Saaty, T.L., Vargas, L.G., 2001. Models, methods, concepts \& applications of the analytic hierarchy process, Massachussets: Kluwer Academic Publisher.

Saaty, T.L., 2008. Decision making with the analytic hierarchy process. International Journal of Services Sciences, 1(1), p.83. 
Samaranayake, P., 2012. Aircraft maintenance planning and scheduling: an integrated framework. Journal of Quality in Maintenance Engineering, 18(4), 432-453.

Sarker, R.A., Haque, A., 2000. Optimization of maintenance and spare provisioning policy using simulation. Applied Mathematical Modeling 24, 10, 751-760.

Saunders, M., Lewis, P. and Thornhill, A., 2016. Research methods for business students, 7th edition, Harlow: Pearson Education Limited.

Scott, J.A., Ho, W., Dey, P.K., 2013. Strategic sourcing in the UK bioenergy industry. International Journal of Production Economics, 146, 478-490.

Simon, H.A., 1977. The New Science of Management Decision, $3^{\text {rd }}$ edition, Eaglewood-Cliff: Prentice-Hall.

Srinivasan, M., Bowers, M.R., Gilbert, K., 2014. Lean Maintenance Repair and Overhaul, New York: McGraw-Hill

Stoll, J. et al., 2015. Criticality analysis of spare parts management: a multi-criteria classification regarding a cross-plant central warehouse strategy. Production Engineering, 9(2), 225-235.

Subramanian, N. and Ramanathan, R., 2012. A review of applications of Analytic Hierarchy Process in operations management. International Journal of Production Economics, 138(2), pp.215-241.

Sun, L., Zuo, H., 2010. Multi-echelon inventory optimal model of civil aircraft spare parts. 2010 Chinese Control and Decision Conference, CCDC 2010, 824-828.

Syntetos, A.A., Keyes, M., Babai, M.Z., 2009. Demand categorisation in a European spare parts logistics network. International Journal of Operations \& Production Management, 29(3), 292-316.

Teunter, R.H., Babai, M.Z., Syntetos, A.A., 2010. ABC Classification : Service Levels and Inventory Costs. Production and Operations Management, 19(3), 343-352.

Trutnevyte, E., Stauffacher, M., Scholz, R.W., 2012. Linking stakeholder visions with resource allocation scenarios and multi-criteria assessment. European Journal of Operational Research, 219, 762-772.

Turban, E., Sharda, R., Delen, D., 2011. Decision Support and Business Intelligence Systems, $9^{\text {th }}$ edition, New Jersey: Pearson Education Inc.

Vaidya, O.S. \& Kumar, S., 2006. Analytic hierarchy process: An overview of applications. European Journal of Operational Research, 169, 1-29.

Vieira, D.R. \& Loures, P.L., 2016. Maintenance, Repair and Overhaul ( MRO ) Fundamentals and Strategies : An Aeronautical Industry Overview. International Journal of Computer Applications, 135(12), 21-29.

von Winterfeldt, D., Fasolo, B., 2009. Structuring decision problems: A case study and reflections for practitioners. European Journal of Operational Research, 199, 857-866.

Voss, C., Tsikriktsis, N., Frohlich, M., 2002. Case Research in Operations Management, International Journal of Operations \& Production Management, 22(2), 195-219.

Wang, N.C. \& Kang, R., 2007. Analyzing of spares inventory management policy based on the analytic hierarchy process., (Xu 1999), 2037-2044.

Wang, W., Yue, S., 2015. An inventory pooling model for spare units of critical systems that serve multi-companies. Transportation Research Part E: Logistics and Transportation Review, 76, 34-44.

Wong, H., van Houtum, G.J., Cattrysse, D., van Oudheusden, D., 2006. Multi-item spare parts systems with lateral transshipments and waiting time constraints. European Journal of Operational Research, 171, 1071-1093.

Yin, R.K., 2014. Case Study Research: Design and Methods, $5^{\text {th }}$ edition, London: Sage Publications. 
Zhou, P. \& Fan, L., 2007. A note on multi-criteria ABC inventory classification using weighted linear optimization. European Journal of Operational Research, 182, 14881491. 